\title{
Histopathological And Immune Response Against Infectious Bursal Disease In Chickens Vaccinated Against Newcastle
}

\section{Disease}

\author{
A.Z.AL Zubeedy A.A. Shamaun A.M.Al-Aalim \\ Coll. of Vet. Med. / Unive. of Mosul
}

\begin{abstract}
Two different vaccination programs against chicken infectious bursal disease (IBD) were compared. Results showed the first program including IBD vaccination at 8 and $16^{\text {th }}$ day old as well as ND vaccination(live attenuated and inactivated types ) give high antibody titers at 21 days post vaccination with significantly difference $(\mathrm{P} \leq 0.0005)$ in comparison with the second program including only IBD vaccine . serological antibodies titer were determined to study the correlation between two different programs using ELISA test. pathological changes in vaccinated groups reveals mild \& moderate lesions appear in liver, spleen and bursa of fabricius
\end{abstract}

Key word : IBD,ND, vaccination, ELISA test ,Broiler, histopathology .

\section{Introduction}

Infectious bursal disease (IBD) is an acute and highly contagious viral disease affecting young chickens and is characterized by massive damage of bursa of fibricius and immunosuppression $(1,2,3)$. The infectious bursal disease virus (IBDV) belongs to the family Birnaviridae its genome composed of two segments of double $\quad$-stranded non-enveloped RNA $(2,4,5,6)$, its highly importance problem in poultry industry .single or multiple IBD vaccines used in commercial flocks to induce vigorous antibody responses and obtain a high and long-lasting immunological response $(2,7)$ the using of another type of vaccine as Newcastle disease

\section{Materials and methods}

Experimental design :- total 45 one day old broiler chicks housed and kept adlbidu feed on concentrated feed . all Chicks is not treated with antibiotic or vaccinated previously, and divided into three groups each having 15 birds.first group chicks were vaccinated 1.7.14.th day old with $0.1 \mathrm{ml}$ live ND vaccine orally, 3day old with $0.1 \mathrm{ml}$ inactivated ND vaccine subcutaneously and $8,16^{\text {th }}$ day old with 0.1 $\mathrm{ml}$ live IBD vaccine orally.Second group chicks were vaccinated 8,16 th days old with $0.1 \mathrm{ml}$ live IBD vaccine orally. Third group vaccine NDV effect on protection against (IBD), ND is one of most important viral disease of poultry .control is possible but require an efficient application of vaccines. In order to prevent both IBD and ND inactivated and activated vaccine have been used to cause significant decrease in incidence of both infection also antigenic interference between two viral vaccines which depend on the type of vaccine ,age and immune state, may effect on histological and immune protection in chicks $(8,9,10)$ .The objective of the study presented here was to investigate the histological and immune response of two different vaccinal programs against IBD.

serves as control group and remain without any vaccination

Blood collection and serological test :-

Blood serum samples from all groups were collected at 21 days of age .serum sample were analyzed by indirect ELISA (Enzymes Linked Immunosorbent Assay)to detect antibodies against $\operatorname{IBD}(6,8,11,12)$.

Macroscopic and histopathological study: Observation for gross lesion was performed after postmortem on different organs (liver spleen , bursa of fibricius) and pathological changes were reported semi-quantity.Tissue 


\section{$\begin{array}{llll}\text { AL-Qadisiya Journal of Vet.Med.Sci. } & \text { Vol./12 } & \text { No./1 }\end{array}$}

samples were taken for study of pathological changes at 21 days post vaccination from bursa of fibricius, liver and spleen from animals of all groups of experimental chicks .The organs were fixed with 10 neutral buffer formalin and processed for paraffin embedding for preparation of $4-6 \mu \mathrm{m}$ histopathological section and stained with heamatoxylin and eosin(13)

\section{Results}

Result of titer antibody IBD in groups compared with control group in 21 different groups are shown in table 1 days, Postmortem changes in vaccinated .significant difference was found between the antibody titer of vaccinated groups at 21 days post vaccination and significant difference was found between vaccinated groups show moderate conjestion with inflammation in group 2 comparing with group1 in different organs and no changes appear in group 3 table 2 .

Table 1 :ELISA antibody titer against IBDV in experimental group

\begin{tabular}{|l|l|l|}
\hline Group no. & \multicolumn{2}{|l|}{ IBD antibody titer mean \pm SD } \\
\hline G1 & $13.542 \pm 2.606$ & A \\
\hline G2 & $10.125 \pm 1.951$ & B \\
\hline G3 & $2.433 \pm 2.843$ & C \\
\hline
\end{tabular}

A-C values with a column followed by different letters are significantly different $(\mathrm{P}<0.0005)$.

Table2:postmortem changes of different organs

\begin{tabular}{|c|c|c|c|}
\hline Group no. & spleen & Liver & Bursa of fabricius \\
\hline G1 & + & + & + \\
\hline G2 & ++ & + & ++ \\
\hline G3 & - & - & - \\
\hline
\end{tabular}

(-) no change

(+) mild conjestion (++) moderate conjestion with enlargement

The post-vaccinal reactions gross and histopathological lesions observed in birds following ND and IBD vaccines. At 21 of age abnormal gross findings were detected in both G1 and G2, the lesions were characterized by mild congestion of spleen, liver and bursa of Fabricius in G1, while in G2 at 21 age lesions were characterized by moderate congestion with mild enlargement in spleen and bursa of Fabricius, and moderate congestion in liver. At 21 of age histopathological lesions were detected in both groups, sections from bursa of Fabricius in G1 showed mild lymphocyte depletion from bursal follicles, while in G2 showed mild lymphocyte depletion from bursal follicles, congestion of blood vessels, edema and infiltration of mononuclear cells in interfollicular spaces (Fig.1 A,B). Sections of spleen in G1 revealed mild lymphocyte depletion in splenic lymphoid follicles, but in $\mathrm{G} 2$ sections revealed mild lymphocyte depletion in splenic lymphoid follicles was the most prominent lesion found, the lymphocyte depletion was characterized by fewer lymphocytes than normal, in addition, in G2 there were thickening of splenic arterial wall (Fig.1C,D). In both groups, livers showed vacuolar degeneration in hepatocytes, congestion and cuffing of blood vessels. 


AL-Qadisiya Journal of Vet.Med.Sci. $\quad$ Vol./12 $\quad$ No./1 2013

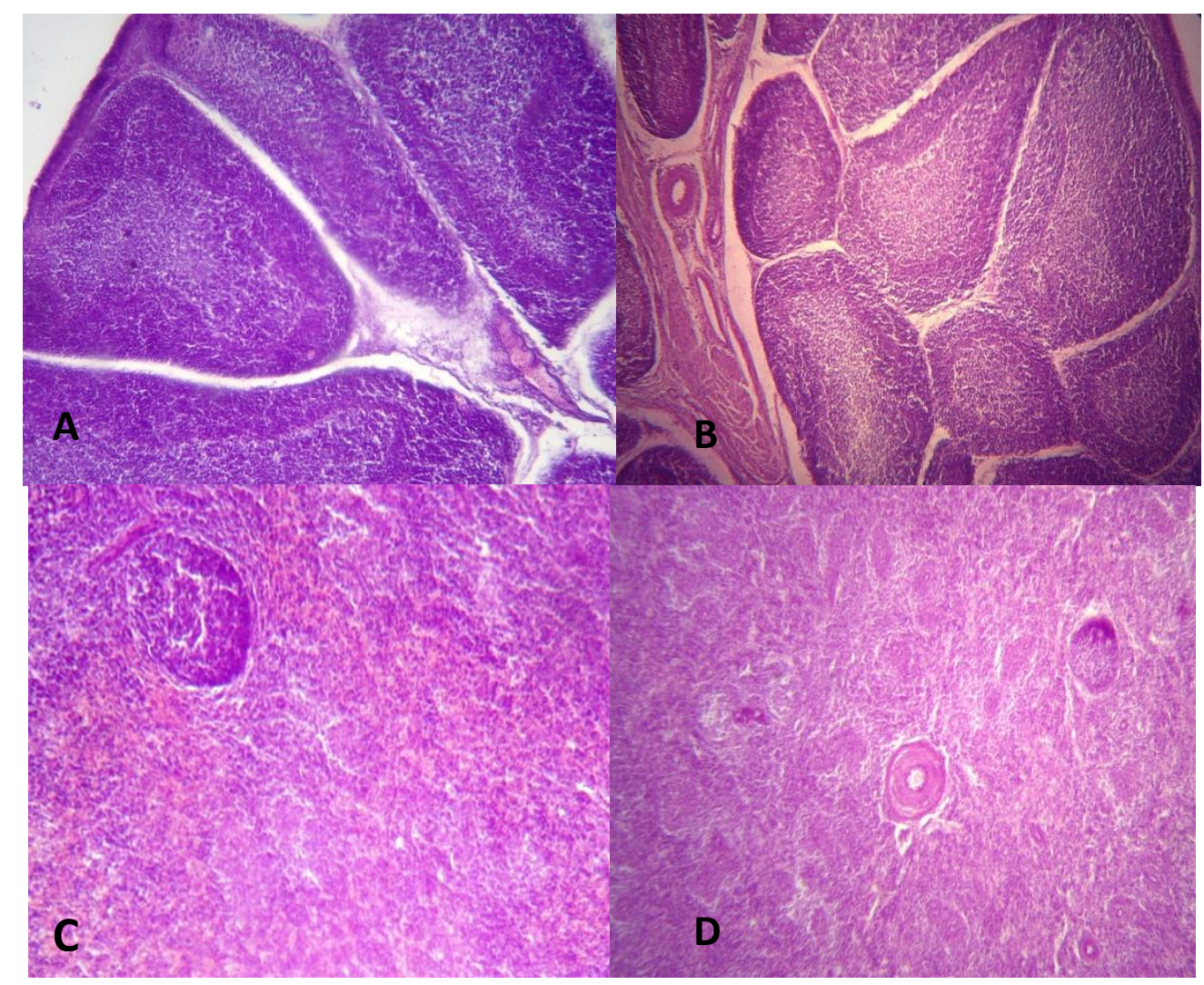

Fig.1 A: section of the bursa of Fabricius from G1 showed mild lymphocyte depletion from bursal follicles. H\&E.(165X).

B:A section of the bursa of Fabricius from G2 showed mild lymphocyte depletion from bursal follicles, congestion of blood vessels, edema and infiltration of mononuclear cells in interfollicular spaces. H\&E.(165X).

C: A section of the spleen from G1 showed mild lymphocyte depletion in splenic lymphoid follicles. H\&E.(145X).

D:. A section of the spleen from G2 showed moderate lymphocyte depletion in splenic lymphoid follicles, thickening of splenic arterial wall. H\&E.(100X).

\section{Discussion}

The basic for infectious bursal disease prevention is specific immunoprophylaxis $(1,14)$ the protective efficacy of vaccine depends on its capability to induced a vigorous and long lasting response in the immune system, ELISA is a routine test for diagnosis of IBDV in the field conditions and for titration of serum antibodies $(3,7)$.the result from the present study showed that the first program is more protective than second program depending on ELISA antibody titers refers to efficacy of immunization is closely related to the type of vaccine used as well as the present study considered that sufficient production against IBD could be achieved by early vaccination of the birds and this suggested in the similar work with $(10,15,16)$ also the oil based vaccine make a depot at the inoculation site and released slowly through antigen processing cell for cytokine production and plasma cell for antibody secretion and the application of live and inactivated vaccine cause immediate local tissue immunity and dispense antigen 
slowly providing progressive stimulation of immunity while acquired material immunity is decline $(9,17,18$,$) and this give high titer$ of antibody against ND program only in the first part of this study and program of vaccination against ND and IBD give the second degree of protection in comparision with the program of vaccination against IBD only (8) as well as vaccination against IBD is more stress to the chicks in small days of old(7) . The maternal derived antibodies against IBD in 21 dayold of third group (control group)was lower in comparison with other groups depending on ELISA antibody titer agreeing with $(2,6,18)$. the histolopathological changes in liver, spleen and bursa of fabricius as sequel of post vaccinal reactions but the pathological changes are more characteristic in the mild depletion of lymphocyte from the follicles of fabicius result from necrosis of these cells by live vaccine(19).

\section{Conclusion}

Our study revealed that early vaccination of broiler chicks against IBDwith the ND in both types (attenuated

and inactivated) give good antibody response in 21 dayes of age post vaccination.

\section{Acknowledgements}

The authors extend thanks to Prof.Dr.M.Y.Al-Attar for reviewing the manuscript and to the College of Veterinary

\section{Reference}

1- kulikova ,I. ; Jurajda, V. and Juranova ,R. (2004).Effect Of Bursal Disease Vaccination Strain On The Immune System Of Leghoran Chicken. ACTA. Vet. Brno., 73;205-209.

2- Cardoso WM. ; Aguiar Filho JLC . and Romao JM.(2006). Interferance Of Infectious Bursal Disease Virus On Antibody Production Against Newcastle Disease And Infectious Bronchitis Virus . Brazilian journal of poultry science . 8 (3);.177-182.

3- Muhammad K.; Rabb F. and Hussain I. (2001). Passive Immunization Against Infectious Bursal Disease In Chicks . international journal of agriculture and biology zool. 034:413-415.

4- Arshad M.,Siddique M. and Ashraf M.(2005). Effect Of Selenium Supplementation On Antibody Titers Against Infectious Burcal Disease Vaccine in broiler chicks.pakistan vet.j.25(4):203-204.

5- Mudasser h., Hussain I. and Irshad H. (2006). immunogenicity of formaldehyde and binary ethylenimine inactivated infectious bursal disease virus in broiler chicks . J.Zhejiang Univ. Sci. 7(8); 660-664.

6- Ahmmad Z and Akhter S.(2003). Role Of Maternal Antibodies Protection Against Infectious Bursal Disease In Commercial Broilers. International $\mathrm{J}$. of poultry science .2(4);. 251-255.

7- Marangon S and Busan L. (2006). The Use Of Vaccination In Poultry Production . Rev.Sci. Tech. Off.Int. Epiz. 26(1);. 265-274.

8- Al Zubeedy A.Z. (2009).Evaluation Of Tow Different Vaccination Programs Against Newcastle Disease In Nineveh Province. J. of animal and Veterinary advance. 8(11);:2228-2231.

9- Giambrone J. J. and Clay Ronald P. (1986).Vaccination Of Day Old Broiler Chicks Against Newcastle Disease And Infectious Bursal Disease Using Commercial Live And /Or Inactivated Vaccines. Avian diseases. 30(3);.557-561.

10- Erchanis O. and Sucan U. (2003).Evaluation Of Three 
$\begin{array}{llll}\text { AL-Qadisiya Journal of Vet.Med.Sci. } & \text { Vol./12 } & \text { No./1 } & 2013\end{array}$

Different Vaccination Regimes

Against Newcatle Disease In Central Antolia. TUR.J.Vet.Anim. Sci. 27;1065-1069.

11- Sheehan A.A. (2010). Interference Of Maternal Immunity With Immuneresponse Of Broiler Chicks Vaccinated With Gumboro Vaccine . MSc. Thesis ;Vet. med. Vet. Microbiol . Mosul .iraq ..

12- Lukert P.D. and Saf Y.M.(2003 ). Infectious Bursal Disease . In Disease Of Poultry . Edited by Saf.Y.M. , Barns H. and Yodo H. .11 th ed . Iowa state University press, Amee, Iowa ,U.S.A. pp:161180.

13- Samuelson ,D.A.(2007).Text Book Of Veterinary Histology , Saunders Elsevier ,ST.louis, Missouri. pp110.

14- Juranova R. and Jurajda L. (2001). Pathogenicity Of Czeeh Isolates Of Infectious Disease Virus. Acta . Vet. Brno. 70;425-431.

15- Erganis O. , Okur A. and Cicek S. (1997). Estimation Of Laboratory And Field Findings for The Use Of
Inactivated Vaccine Against Newcastle Disease. Veterinarium . $8 ; 57-59$.

16- Tran vui.,Lohr J.E. and Baumann M.P.O.(2002) . Antibody Levels Against Newcastle Disease Virus , Infectious Bursal Disease Virus And Avian Influeneza Virus In Rural Chickens In Vietnam .Inter.j.poult.sci.1(5):127-132.

17- AL-natour M.O., Ward L.A. and Keck L.D. (2004).Effect Of Different Level Of Maternally Derived Antibodies On Protection Against Infectious Bursal Disease. Avian Disease. 48:177-187.

18- Hair-Bejo M. , Salina ,S., Hafia H. and Julada S. (2000).In ova Vaccination Against Infectious Bursal Disease In Broiler Chickens . J.Vet. Malaysis. 12:63-69.

19- AL-Jubori , F.M. (2009).The Post Vaccinal Changes Of IBDL And D78 Strains Against Infectious Bursal Disease In Broiler Chickens . MSc. Thesis . University of Mosul, Mosul, Iraq .

\section{دراسة الاستجابة المناعية والمرضية النسجية ضد مرض التهاب كيس فابرشيا

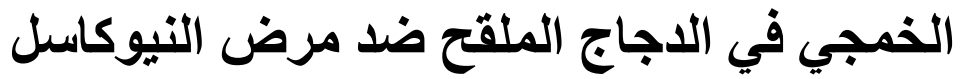

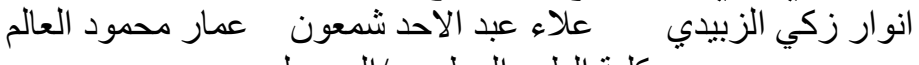$$
\text { كلية الطب البيطري /الموصل }
$$

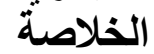

تم مقارنة برنامجي تحصين ضد مرض التهاب كيس فابريشيا الخمجي في الدو اجن .اظهرت النتائج ان البرنامج الاول

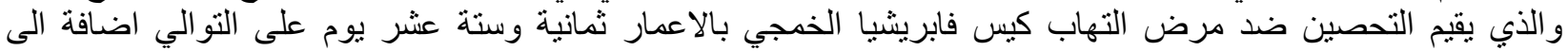

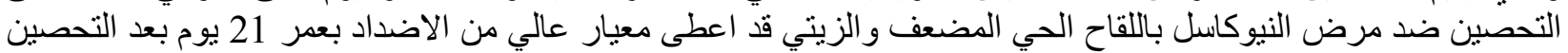

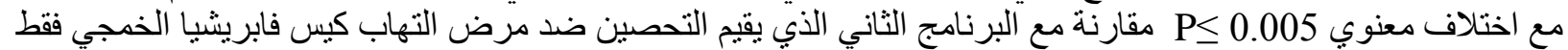

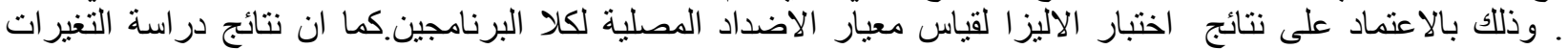

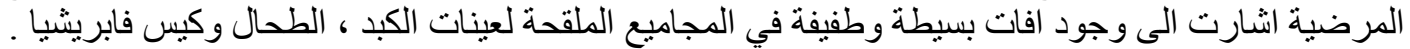

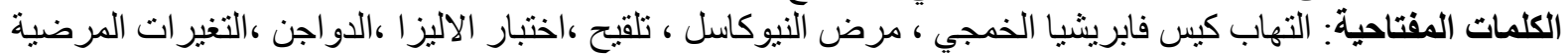

